\title{
A new species of Dianthus (Caryophyllaceae) from Antalya, South Anatolia, Turkey
}

\author{
İsmail Gökhan Deniz', Candan Aykurt² ${ }^{2}$ İlker Genç³, Ahmet Aksoy² \\ I Department of Biology Education, Faculty of Education, Akdeniz University, Antalya, Turkey 2 Department \\ of Biology, Faculty of Science, Akdeniz University, Antalya, Turkey 3 Istanbul University, Faculty of Pharmacy, \\ Department of Pharmaceutical Botany, Istanbul, Turkey
}

Corresponding author: İsmail Gökhan Deniz (gdeniz@akdeniz.edu.tr)

Academic editor: Cl. Morden | Received 4 February 2016 | Accepted 22 April 2016 | Published 26 April 2016

Citation: Deniz İG, Aykurt C, Genç İ, Aksoy A (2016) A new species of Dianthus (Caryophyllaceae) from Antalya, South Anatolia, Turkey. PhytoKeys 63: 1-12. doi: 10.3897/phytokeys.63.8033

\begin{abstract}
Dianthus multiflorus from Gazipaşa (Antalya), south Anatolia (Turkey), is described as a new annual species with verrucose calyx. The morphological differences from the species within the same group with $D$. multiflorus, which are D. aydogdui, D. cyri and D. tripunctatus, are discussed. The International Union for Conservation of Nature (IUCN) threat category and observations on the ecology of the populations are noted. The karyology and seed micromorphology of D. multiflorus and D. tripunctatus were examined by light microscopy and scanning electron microscopy.
\end{abstract}

\section{Keywords}

Dianthus, new species, taxonomy, Turkey

\section{Introduction}

Amongst all its neighbouring countries, Turkey is the richest in terms of plant taxa, being home to 9996 plant species (11707 taxa) (Güner et al. 2012). The floristic richness of the country is partially due to the high number of endemic and rare species present. The Mediterranean region is one of the important centers of endemism in Turkey, and Antalya is the richest province of Turkey in terms of plant diversity, 
hosting 773 of the country's endemic species. Amongst these endemic species, about 244 are best described as locally endemic, being found only in Antalya (Deniz and Aykurt 2014).

After Silene L., Dianthus L. is the second largest genus of Caryophyllaceae. This genus, containing approximately 300 species, is mainly distributed in the Mediterranean region of Europe and Asia (Reeve 1967; Bittrich 1993). The most comprehensive study on Dianthus species in the Flora of Turkey and East Aegean Islands was carried out by Reeve (1967) wherein 67 species were recorded. Since that date, new species and records have been added and the total number of Dianthus species recorded in Turkey has increased to 81 (Shishkin 1985, Davis et al. 1988, Gemici and Leblebici 1995, Güner 2000, Menemen and Hamzaoğlu 2000, Aytaç and Duman 2004, Özhatay and Kültür 2006, Vural 2008, Yılmaz et al. 2011, İlçim et al. 2013, Hamzaoğlu 2012, Hamzaoğlu and Koç 2015, Hamzaoğlu et al. 2014, 2015a, 2015b, 2015c). Among the annual Dianthus species recognized by Reeves (1967), there are only two species (D. cyri Fisch. \& C.A.Mey. and D. tripunctatus Sm.) that have a verrucose calyx.

Dianthus aydogdui Menemen \& Hamzaoğlu, which resembles D. cyri and D. tripunctatus, has been described from Salt Lake (Central Anatolia) province by Menemen and Hamzaoğlu (2000). The new species described here, Dianthus multiflorus Deniz \& Aykurt, was collected from Gazipaşa province in Antalya. It is distributed on stony sliding slopes and serpentine soils in clearings of Pinus brutia forest. Dianthus multiflorus is included in the same group along with D. aydogdui, D. cyri and D. tripunctatus. Dianthus multiflorus shows distinct differences from these species by its habit, number of flowers on the stem, calyx and petal features.

\section{Methods}

\section{Plant samples and morphological studies}

Dianthus multiflorus specimens were collected from Gazipaşa province (Antalya) during field studies within the scope of the project "EXPO 2016 Endemic and Rare Flowers of Antalya". New species and its morphologically most similar species, D. tripunctatus were observed during field studies and their morphological characteristics were recorded both in the field and in the laboratory. Specimens collected were comprehensively evaluated by the use of the literature (Velenovsky 1891; Post 1932; Tutin 1964; Reeve 1967; Shishkin 1985; Strid 1986; Rechinger 1988) and the specimens present in GAZI, ISTE, and Akdeniz University herbariums. The overall morphology of the new species was examined with stereo-binocular microscope.

The seed micromorphology of D. multiflorus and D. tripunctatus was investigated using scanning electron microscopy (SEM) techniques. Seeds were attached to SEM stubs, coated with gold conjugate following the manufacturer specifications and examined with a Zeiss LEO-1430 scanning electron microscope. 


\section{Karyological studies}

Chromosome number and karyological features of the Dianthus multiflorus and D. tripunctatus were determined from plant material collected from Antalya. All karyological observations were carried out on root tips. Root-tip meristems were provided from seeds by germinating them on wet filter paper in petri dishes at the temperature of $23^{\circ} \mathrm{C}$. Firstly, root tips were pretreated for $24 \mathrm{~h}$ in a-monobromonaphthalene at 4 ${ }^{\circ} \mathrm{C}$, fixed in 3:1 absolute alcohol-glacial acetic acid. Root tips were then hydrolyzed with $1 \mathrm{~N} \mathrm{HCL}$ for $13 \mathrm{~min}$. at $60^{\circ} \mathrm{C}$, stained in Feulgen solution, and squashed in acetoorcein. For karyotype analysis, the photographs were taken using OLYMPUS BX53 microscope with camera Kameram 12 CCD attachment. Chromosome counts in mitosis metaphase and karyotype analyses were obtained based on five root tips, five metaphase cells for each individual. Measurements of somatic chromosomes were made with the program KAMERAM, they were calculated with formula of the relative variation in chromosome length $\mathrm{CV}_{\mathrm{CL}}$ (Paszko 2006), mean centromeric asymmetry $\left(\mathrm{M}_{\mathrm{CA}}\right)$ according to Peruzzi and Eroğlu (2013) and chromosome total haploid length (THL) (Peruzzi et al. 2009). Chromosomes were classified to the nomenclature following Levan et al. (1964) and asymmetry types following Stebbins (1971).

\section{Results}

With the recognition of Dianthus multiflorus as a new species, there are now four annual species of Dianthus, (D. multiflorus, D. tripunctatus, D. cyri and D. aydogdui) that can be separated from other annual Dianthus species on the basis of their verrucose calyxes in Turkey. A detailed comparision of the morphological and ecological features of these species is shown in the Table 1 .

\section{Dianthus multiflorus Deniz \& Aykurt, sp. nov.} urn:Isid:ipni.org:names:77154520-1

Figs $1-4$, Table $1-2$

Diagnosis. Dianthus multiflorus is distinguished from related species by having flowers numerous [(30-)80-250(-300)], pedicels $0.5-30 \mathrm{~mm}$, calyx $12-13 \mathrm{~mm}$, petals white, and petal limb margins shallowly sinuate.

Type. TURKEY. Antalya: Gazipaşa, from Akoluk Village to Akkaya Hill of Taşeli Plateau, c. $3 . \mathrm{km}$, stony sliding slopes and serpentine soils in clearings of Pinus brutia forest, 1075 m a.s.l., 05 July 2015, I.G. Deniz, C. Aykurt, 6195 (holotype: Akdeniz University Herbarium 3823).

Annual, many-stemmed, divaricately branched herbs. Stem erect to ascending, fragile, slender, $20-80 \mathrm{~cm}$, branching from the base, glabrous or minutely scabridulous especially toward base, usually purplish at base, many-flowered (30-)80-250(-300). Basal 


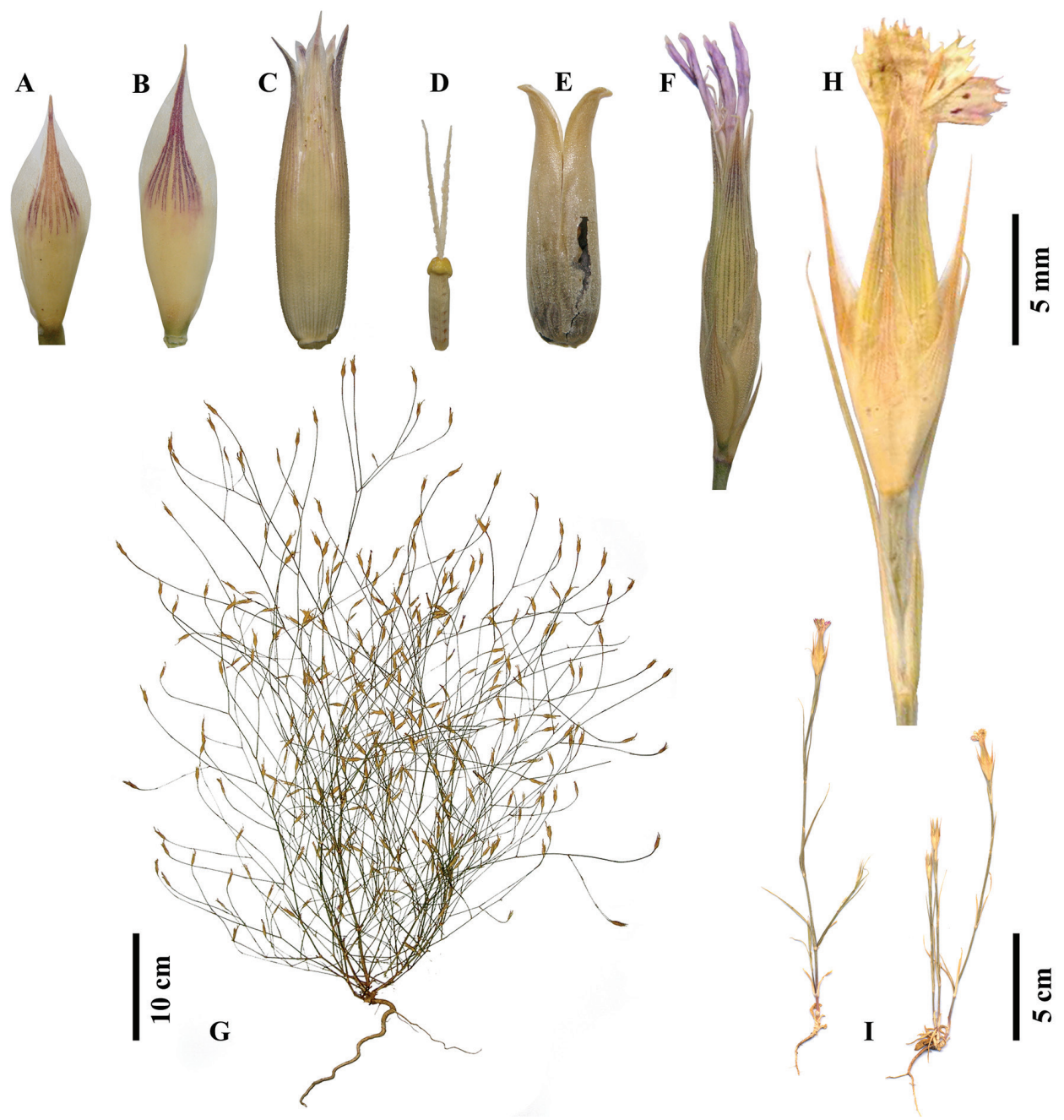

Figure I. Habit and flower photographs of Dianthus multiflorus (A-G from holotype, Deniz 6195) and D. tripunctatus (H-I from ISTE 74221). (A Outer epicalyx segment B Inner epicalyx segment C Calyx D Pistil E Capsule F, H Flower G, I Habit).

leaves linear-lanceolate to lanceolate-spatulate, $25-35 \times 2.5-4.5 \mathrm{~mm}$, with scabridulous edges especially near base, obtuse at apex. Cauline leaves linear-narrowly triangular to linear-lanceolate, gradually smaller upwards, flattened, distinctly nervous, glabrous, with scabridulous margin and narrowly membranous toward base, acute to acuminate at apex, their sheaths shorter than the internodes; lower cauline leaves linear-lanceolate, 20-50 $\times$ 2-2.2 mm, longer or shorter than internodes, swollen and usually purplish at base; upper cauline leaves linear to linear-narrowly triangular, $4-20 \times 0.5-1.5 \mathrm{~mm}$, slightly swollen at base. Inflorescence dichotomously branched; flowers almost always solitary, occasionally two or three flowers borne on the same nod; branches usually minutely scabridulous; 
Table I. Comparison of diagnostic morphological characters of Dianthus multiflorus with its close relatives.

\begin{tabular}{c|c|c|c|c}
\hline Characters & D. multiflorus & D. tripunctatus & D. cyri & D. aydogdui \\
\hline Plant size (cm) & $20-80$ & $20-50$ & $12-40$ & $3-15$ \\
\hline Flowering stem & Divaricately branched & Many branched & Many branched & Single stemmed \\
\hline Epicalyx scales length & $\begin{array}{c}\text { Almost equaling or } \\
\text { shorter than calyx tube }\end{array}$ & $\begin{array}{c}\text { Equaling calyx } \\
\text { tube }\end{array}$ & $\begin{array}{c}\text { Equaling or longer } \\
\text { than calyx tube }\end{array}$ & $\begin{array}{c}\text { Shorter than calyx } \\
\text { tube }\end{array}$ \\
\hline $\begin{array}{c}\text { Epicalyx scales mucro } \\
\text { length (mm) }\end{array}$ & $3-3.5$ & $3-8$ & $7-12$ & $1-3$ \\
\hline Pedicels length (mm) & $0.5-30$ & $40-50$ & $15-35$ & $5-15$ \\
\hline Number of flowers & $\begin{array}{c}\text { Numerous (30-) } \\
80-250(-300)\end{array}$ & $4-15(-40)$ & $5-22$ & $1-4$ \\
\hline Calyx length (mm) & $12-13$ & $18-20$ & $11-15$ & $8-10$ \\
\hline Calyx tube & Distinctly 35-40 nerved & Nervose-striate & Enervate & Nervose \\
\hline Apex of calyx teeth & Acuminate & Acuminate & Aristate & $\begin{array}{c}\text { Acute sometimes } \\
\text { mucronate }\end{array}$ \\
\hline Petal limb color & $\begin{array}{c}\text { White with purple } \\
\text { venation }\end{array}$ & Pink & Pink & Pink \\
\hline Margin of petal limb & $\begin{array}{c}\text { Emerginate with } \\
\text { shallowly sinuate lobes }\end{array}$ & Dentate & Dentate & Dentate \\
\hline Ecology & $\begin{array}{c}\text { Sliding slopes and } \\
\text { serpentine soils }\end{array}$ & Cliffs, road sides & Deep alluvial soils & Salty soils \\
\hline Altitude & $1000-1150 \mathrm{~m}$ & $1-120 \mathrm{~m}$ & $1200 \mathrm{~m}$ & $950 \mathrm{~m}$ \\
\hline
\end{tabular}

pedicels $1-30 \mathrm{~mm}$ (sometimes very short, to $0.5 \mathrm{~mm}$ ). Epicalyx scales 4, almost equaling or shorter than calyx tube, cartilaginous, straw-colored, markedly 8-nerved toward apex, glabrous, verrucose at middle and below surfaces, scabridulous at apex and on scarious margins; scarious margins terminating at or under apex; outer epicalyx segments obovate, 8-9 $\times 3-3.5 \mathrm{~mm}$, with acuminate tip (ca. $3 \mathrm{~mm}$ ), scarious margins up to $0.75 \mathrm{~mm}$ broad; inner epicalyx segments obovate, $11-12 \times 4-4.5 \mathrm{~mm}$, with acuminate tip (ca. $3.5 \mathrm{~mm}$ ), scarious margins up to $0.8 \mathrm{~mm}$ broad. Calyx cylindric-lanceolate, verrucose, distinctly $35-40$-veined, usually purplish at upper $2 / 3$ part, $12-13 \times 2.8-3 \mathrm{~mm}$; teeth triangular, $4.5-5.5 \mathrm{~mm}$ long, 7-8-veined, with narrowly scarious and scabridulous margins. Petals white, $20 \mathrm{~mm}$; limb narrowly obovate, $6-7 \times 3 \mathrm{~mm}$, emarginate with shallowly sinuate lobes, completely exerted from calyx, unspotted, barbulate, with 3 main purplish vein; claw $12-13 \times$ ca. $1 \mathrm{~mm}$. Anthers $3.6 \mathrm{~mm}$ long; filaments $7 \mathrm{~mm}$ long. Ovary $3.5 \mathrm{~mm}$ long; style $5 \mathrm{~mm}$ long. Capsule cylindrical, included in calyx, $10 \times 3 \mathrm{~mm}$. Seeds ovate to elliptic, 1.9-2.5 × 1.07-1.7 mm, black, minutely cuspidate at apex, granular, covered by irregularly polygonal or rectangular cells; anticlinal walls represented by shallow and wide grooves, with U-like undulations; the periclinal walls distinctly papillose. The cells of ventral surface $75-145 \times 33.2-59.4 \mu \mathrm{m}$, more elongated and bigger than the cells of dorsal surface $(31.4-86 \times 25-45 \mu \mathrm{m})$.

Distribution, habitat and ecology. Dianthus multiflorus is known only from the type locality, between Akoluk Village to Taşeli Plateau, where it grows at altitude of $1000-1150 \mathrm{~m}$ on sliding slopes and serpentine soils in clearings of Pinus brutia Ten. 


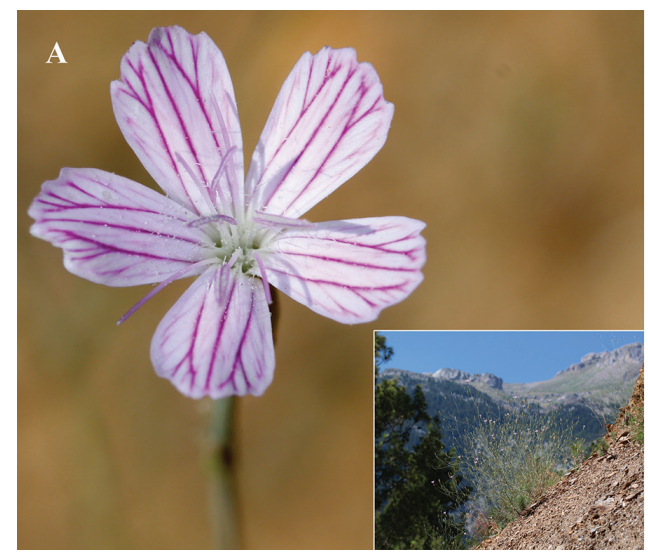

Figure 2. Field photographs of Dianthus multiflorus

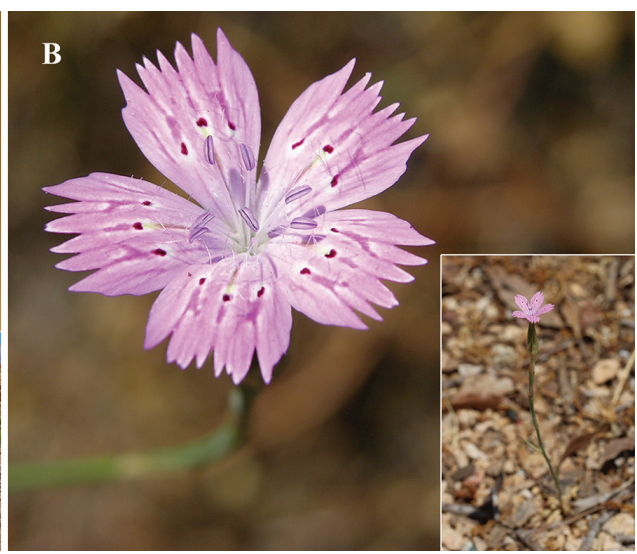

(A) and D. tripunctatus $(\mathbf{B})$.

forest. Within this area, the new taxon is associated with plants such as: Pinus brutia var. brutia, Quercus coccifera L., Helichrysum arenarium Moench subsp. aucheri (Boiss.) P.H.Davis \& Kupicha, Carduus rechingerianus Kazmi, Centaurea urvillei DC. subsp. urvillei, Teucrium lamiifolium d'Urv. subsp. lamiifolium, Thymus cilicicus Boiss. \& Balansa. Ballota saxatilis Sieber ex C.Presl subsp. saxatilis.

Phenology. Dianthus multiflorus was observed flowering in June and July, and mature fruits are produced in July to middle of August.

Etymology. The species epithet is derived from its abundant flowers representing one of the main characters that distinguishes it from other similar species.

Proposed conservation status. Dianthus multiflorus is included in the Critically Endangered category according to IUCN criteria ver. 11 (IUCN 2014). The species was determined at only a single location and the extent of occurrence (EOO) value of the species was determined to be $7 \mathrm{~km}^{2}$ taking into account location of occupancy and the area contained within the shortest continuous imaginary boundary. Additionally, the area of occupancy (AOO) value in this area was calculated as $4 \mathrm{~km}^{2}$ [CR B1ab(i)+CR B2b(ii)].

Seed testa micro-morphology. A detailed comparison of seed micromorphology based on SEM analysis was made (Table 2). The seeds of D. multiflorus and D. tripunctatus are black, minutely cuspidate at apex, granular, and have anticlinal walls represented by shallow and wide grooves, with U-like undulations, while the periclinal walls are distinctly papillose. The seeds of $D$. multiflorus are covered by irregularly polygonal or rectangular cells, and the cells of ventral surface are more elongated and larger, conversely the seeds of $D$. tripunctatus are covered by irregularly rectangular cells and the cell size of ventral and dorsal surfaces are similar (Fig. 3).

Karyology. The chromosome number of Dianthus multiflorus and D. tripunctatus is $2 n=30$ (Fig. 4). The shortest chromosome length for D. multiflorus is $0.54 \mu \mathrm{m}$, the longest is $1.24 \mu \mathrm{m}$, and total haploid chromosome length (THL) is $12.21 \mu \mathrm{m}$. The karyotype formula of $D$. multiflorus consists of 28 median pairs and 2 submedian 

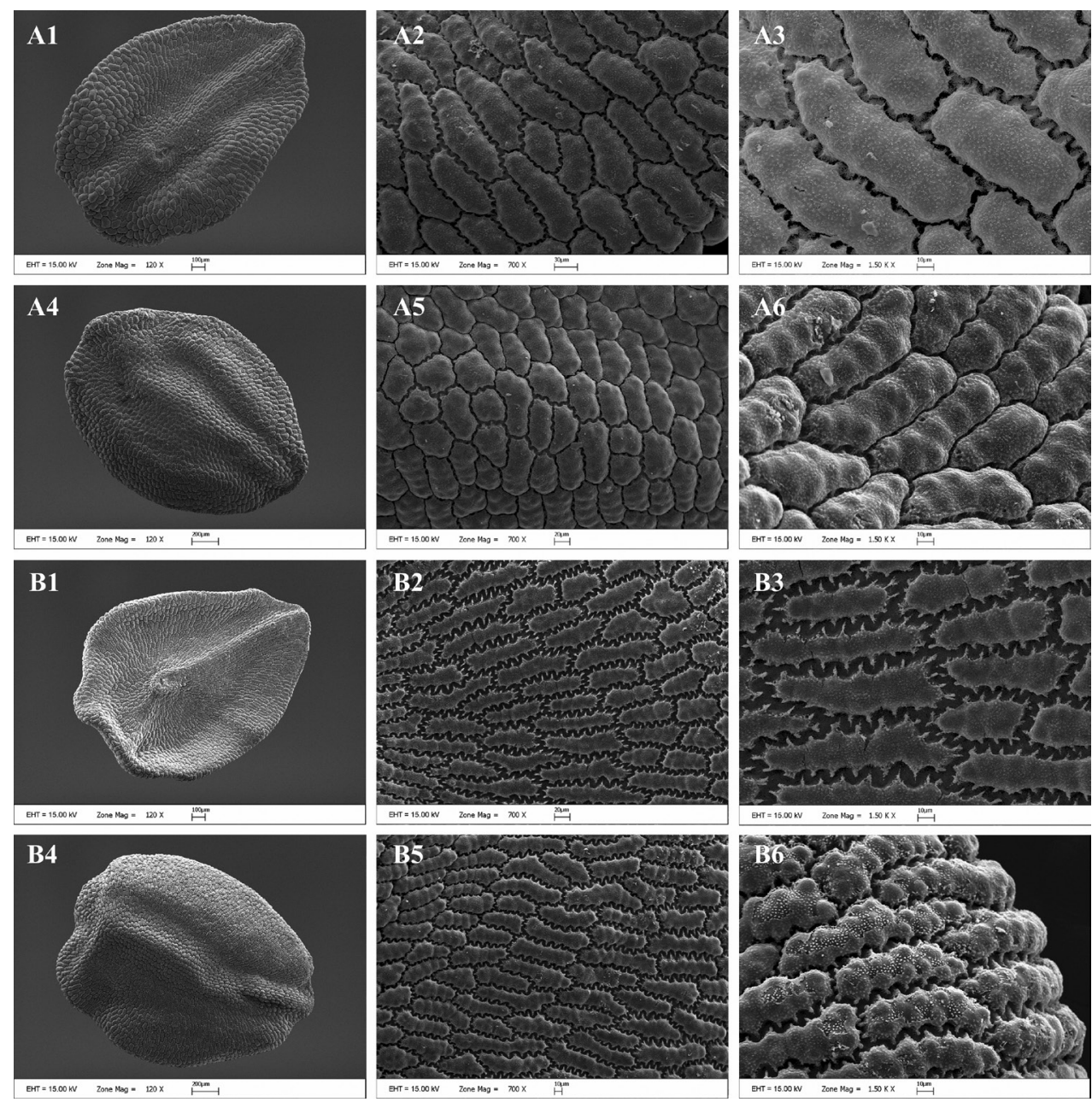

Figure 3. SEM photographs of the seed coat. A Dianthus multiflorus B D. tripunctatus. 1-3: Ventral surface. 4-6: Dorsal surface. (Scale bars $200 \mu \mathrm{m}$ for A4 and B4; $100 \mu \mathrm{m}$ for A1 and B1; $30 \mu \mathrm{m}$ for A2; 20 $\mu \mathrm{m}$ for $\mathrm{A} 5$ and $\mathrm{B} 2 ; 10 \mu \mathrm{m}$ for $\mathrm{A} 3, \mathrm{~A} 6, \mathrm{~B} 3, \mathrm{~B} 5$ and $\mathrm{B} 6$ ).

pairs. As for karyotype asymmetry, its karyotype was classified according to the symmetry classes of Stebbins $(1971)$ as $3 \mathrm{~B}$. Intrachromosomal asymmetry $\left(\mathrm{M}_{\mathrm{CA}}\right)$ is 6.26 and the interchromosomal asymmetry index $\left(\mathrm{CV}_{\mathrm{CL}}\right)$ is 19.93 . Our study showed that the shortest chromosome length for $D$. tripunctatus is $0.77 \mu \mathrm{m}$, the longest is $1.21 \mu \mathrm{m}$, and total haploid chromosome length (THL) is $14.09 \mu \mathrm{m}$. The karyotype formula of this species consists of 28 median pairs and 2 submedian pairs. As for karyotype asymmetry, the karyotype of this species is classified according to the symmetry classes of Stebbins (1971) as 3A. Intrachromosomal asymmetry $\left(\mathrm{M}_{C A}\right)$ is 6.42 and the interchromosomal asymmetry index $\left(\mathrm{CV}_{\mathrm{CL}}\right)$ is 12.57. The karyogram is given in Figure 4 and ideogram was drawn based on the centromeric index (Fig. 4). 
Table 2. Comparison of seed micromorphological and karyological characteristics of Dianthus multiflorus and D. tripunctatus.

\begin{tabular}{|c|c|c|c|}
\hline & Characters & D. multiflorus & D. tripunctatus \\
\hline \multirow{5}{*}{ 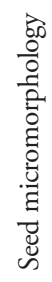 } & Seed size $(\mathrm{mm})$ & $1.9-(2.16)-2.5 \times 1.07-(1.46)-1.07$ & $1.9-(2.07)-2.23 \times 1.4-(1.62)-1.87$ \\
\hline & Cell shape of seed coat & Polygonal or rectangular & Rectangular \\
\hline & Cell size of ventral surface & $75-145 \times 33.2-59.4 \mu \mathrm{m}$ & $(60-) 97.4-127.3 \times 18.2-26$ \\
\hline & Cell size of dorsal surface & $31.4-86 \times 25-45 \mu \mathrm{m}$ & $57-140 \times 18.6-32.9$ \\
\hline & $\begin{array}{l}\text { Cell size of ventral surface } \\
\text { according to dorsal surfaces }\end{array}$ & More elongated and bigger & Similar \\
\hline 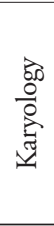 & $\begin{array}{c}\text { SC } \\
\mathrm{LC} \\
\mathrm{THL} \\
\mathrm{M}_{\mathrm{CA}} \\
\mathrm{CV}_{\mathrm{CL}} \\
\text { Stebbins symetry }\end{array}$ & $\begin{array}{c}0,54 \mu \mathrm{m} \\
1.24 \mu \mathrm{m} \\
12.21 \mu \mathrm{m} \\
6.26 \\
19.93 \\
3 \mathrm{~B}\end{array}$ & $\begin{array}{c}0.77 \mu \mathrm{m} \\
1.21 \mu \mathrm{m} \\
14.09 \mu \mathrm{m} \\
6.42 \\
12.57 \\
3 \mathrm{~A}\end{array}$ \\
\hline
\end{tabular}
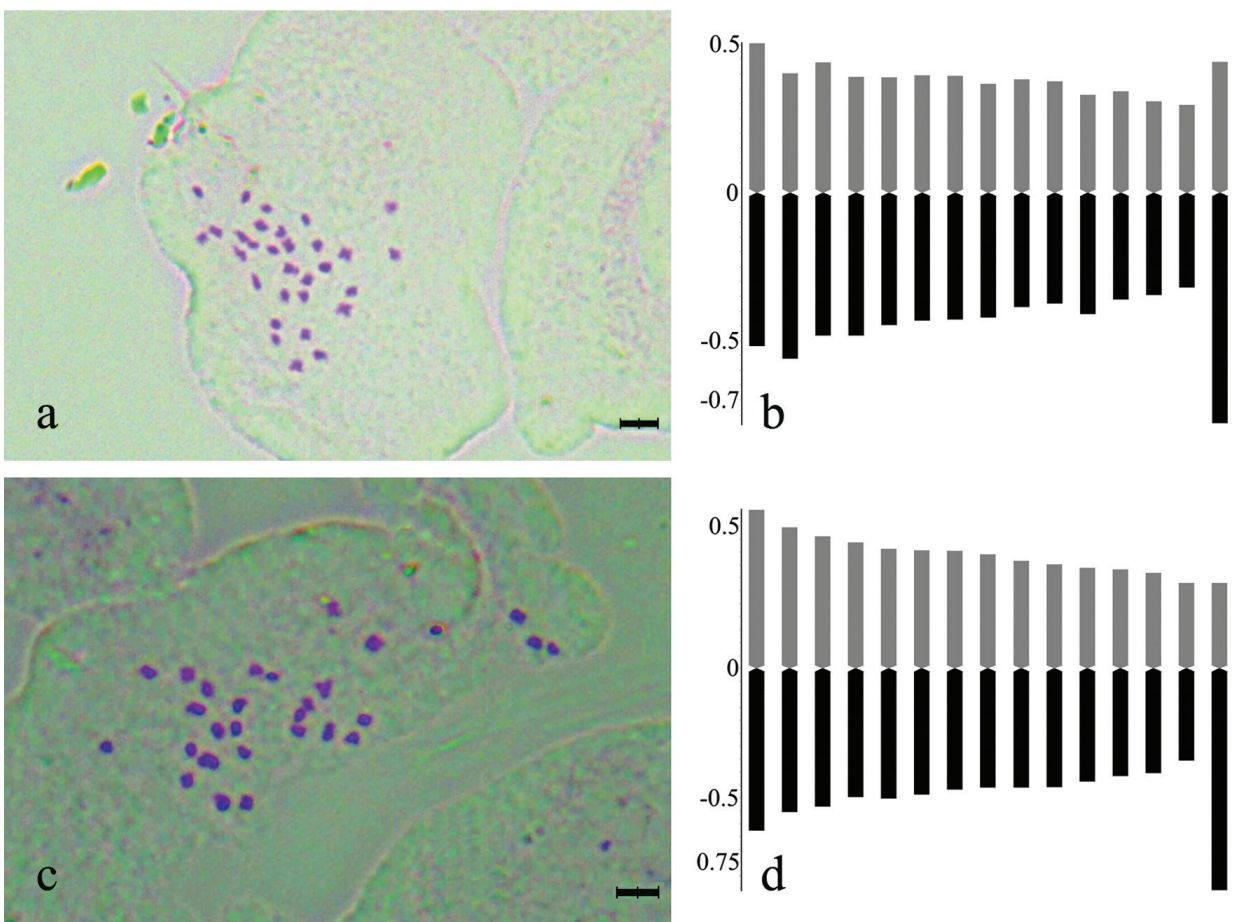

Figure 4. Somatic chromosomes and ideogram of Dianthus multiflorus (a-b) and D. tripunctatus (c-d). (Scale bars $2 \mu \mathrm{m}$ ).

According to Stebbin's (1971) classification, the karyotypes of D. multiflorus belong to type $3 \mathrm{~B}$, whereas the karyotypes $D$. tripunctatus belong to type $3 \mathrm{~A}$. The asymmetry indices also reveal some small differences between the two species. Nevertheless, 
according to interchromosomal asymmetry index $\left(\mathrm{CV}_{\mathrm{CI}}\right)$, D. multiflorus is more asymmetric than $D$. tripunctatus. The total haploid chromosome length (THL) in $D$. multiflorus is $12.21 \mu \mathrm{m}$ and that of D. tripunctatus is $14.09 \mu \mathrm{m}$ (Table 2).

\section{Diagnostic key to the annual Dianthus species with verrucose calyx in Turkey}

1 Stem unbranched, $3-15 \mathrm{~cm}$; calyx $10 \mathrm{~mm}$ or shorter. D. aydogdui

- Stem many branched, $12-80 \mathrm{~cm}$; calyx more than $10 \mathrm{~mm}$ 2

2 Stem bearing (30-)80-250(-300) flowers; petal limb white with purple venation, shallowly sinuate at margins. D. multiflorus

- $\quad$ Stem bearing 4-15(-40) flowers; petal limb pink, dentate at margins..........3

3 Calyx tube nervose-striate; base of epicalyx segments adpressed to the calyx, their membranous margins conspicuous, $2 \mathrm{~mm}$ wide...........D. tripunctatus

- $\quad$ Calyx tube enervate; base of epicalyx segments spreading, their membranous margins inconspicuous, not more than $0.5 \mathrm{~mm}$ wide

D. cyri

\section{Discussion}

Of the annual Dianthus species that occur in Turkey, there are only four species that have verrucose calyxes; Dianthus aydogdui, D. cyri, D. multiflorus and D. tripunctatus. Dianthus aydogdui was recently described from Salt Lake province (Menemen and Hamzaoglu 2000), and this species is distinct from D. tripunctatus and D. Cyri due to its short and single stems, and shorter epicalyx scales in relation to its calyx tube. $D i-$ anthus multiflorus is also closely related to D. tripunctatus and D. cyri. In particular, the habit and floral characteristics of $D$. multiflorus are quite different from other species. Its divaricately branched stems bear numerous flowers unlike those of $D$. tripunctatus and D. cyri. Contrary to the pink and dentate petal-limbs of D. tripunctatus and D. cyri, D. multiflorus has white petals with distinct dark purplish venation and emarginate with shallowly sinuate margins. Dianthus multiflorus shows more resemblance to $D$. tripunctatus than $D$. cyri by the length of its epicalyx scales and the features of calyxes. The calyx tubes of $D$. multiflorus and $D$. tripunctatus are nervose-striate whereas those of $D$. cyri are enervose. However, the calyx length of $D$. multiflorus is shorter than that of $D$. tripunctatus. Further, the epicalyx scales are shorter to almost equaling in the calyx tube in D. multiflorus whereas they are equaling in D. tripunctatus and shorter in D. cyri. Dianthus multiflorus and D. tripunctatus have acuminate calyx teeth compared to their being aristate in C. cyri.

Besides morphological characteristics, both seed micromorphological and karyological features of $D$. multiflorus and $D$. tripunctatus were also identified within the present study. According to the results of the seed micromorphological studies, the main difference between the seeds of D. multiflorus and D. tripunctatus is the shape and size of the coat cells. According to the results of the karyological studies, there are some 
karyomorphological differences between the two species. According to Levin (2002), the correlation between THL and $1 \mathrm{C}$ values within and between species in related genera, THL is considered a good proxy for genome size. On this basis, Peruzzi and Altınordu (2014) proposed a standardized method, taking into account six quantitative parameters, in order to establish relationships among taxa. THL is one of these parameters and the total haploid chromosome length (THL) in D. multiflorus was comparatively lower than that of $D$. tripunctatus.

\section{Conclusion}

The most important reason for the high endemism values in the Antalya and Mediterranean regions of Turkey is the sudden climatic and topographic differences. The Tasseli Plateau, which is one of the endemism centers of the eastern part of the Antalya province, is at an altitude of approximately 2200 meters and is just $20 \mathrm{~km}$ from the Mediterranean Sea. The lower slopes of the region are characterized by a typical Mediterranean climate and vegetation types, but the climatic conditions are continental at higher altitudes. The distribution area of Dianthus multiflorus is located in these climatic and topographic transition regions, and discovery of the new species contributes to a better understanding the richness of the Turkish Flora. With this study, the total number of species belonging to the genus Dianthus has risen to 82 , the study provides material and data to aid further research on Dianthus, an important member of the Caryophyllaceae.

Specimens Examined. Dianthus aydogdui Menemen \& Hamzaoğlu-TURKEY. Aksaray: Salt lake province, The north way from Ulukışla to Salt Lake, 950 m, 24 June 1999, E. Hamzaoğlu \& M. Aydoğdu 2432 (isotype GAZI!); Dianthus cyri Fisch. \& C.A.Mey.-TURKEY: 06 July 1970, F. Sorger 70-43-1 (E!) http://data.rbge.org. uk/herb/E00475274; UNITED ARAB EMIRATES. Fujeirah Coast-Lulayyah: Open fields in shelttered coastal plantation, 26 February 1986, R.A. Western 881 (E!) http:// data.rbge.org.uk/herb/E00181825; Dianthus tripunctatus Sm.-TURKEY. Antalya: Karayolları beach, $40 \mathrm{~m}, 15.6 .1983, H$. \& G. Çakırer s.n. (ISTE 50905!); Antalya: Ulaş Highway recreation park, $20 \mathrm{~km}$ from İncekum to Alanya, s.l., 19 June 1983, $H$. \& G. Çakırer s.n. (ISTE 51106!); Antalya: Kemer, Çıralı, under Pinus brutia, 10 m, 5 May 2013, R. Süleyman Göktürk 7621 (Akdeniz University Herbarium 1779!); İzmir: 30 May 1960, N. Öktem 56 (ISTE 6218!); Muğla: Ortaca, between Dalyan and Tepe, 10-20 m, roadsides, 18 June 1991, A. Güner 9501 (GAZI!).

\section{Acknowledgements}

We wish to thank the subject editor and reviewers for their constructive comments which helped us to improve the manuscript, Agency of EXPO 2016 Antalya for financial support, and the curators of the E, GAZI, ISTE and Akdeniz University Herbarium for specimens examined. 


\section{References}

Aytaç Z, Duman H (2004) Six new taxa (Caryophyllaceae) from Turkey. Annales Botanici Fennici 41: 213-223.

Bittrich V (1993) Caryophyllaceae. In: Kubitzki K, Rohwer J, Bittrich V (Eds) The Families and Genera of Vascular Plants, Magnoliid, Hamamelid, and Caryophyllid Families, Vol. 2. Springer, Berlin, 206-236. doi: 10.1007/978-3-662-02899-5_21

Davis PH, Mill RR, Tan K (1988) Dianthus L. In: Davis PH, Mill RR, Tan K (Eds) Flora of Turkey and the East Aegean Islands (Suppl. 1), Vol. 10. Edinburgh University Press, Edinburgh, 71-72.

Deniz İG, Aykurt C (2014) Critically endangered (CR) plant taxa in Antalya Province. The Herb Journal (21) 2: 59-70.

Gemici Y, Leblebici E (1995) Seven new species for the Flora of Turkey. Candollea 50: 41-50.

Güner A (2000) Dianthus L. In: Güner A, Özhatay N, Ekim T, Başer KHC (Eds) Flora of Turkey and the East Aegean Islands (Suppl. 2), Vol. 11. Edinburgh University Press, Edinburgh, 48-49.

Güner A, Aslan S, Ekim T, Vural M, Babaç MT (Eds) (2012) Türkiye Bitkileri Listesi (Damarlı Bitkiler). Nezahat Gökyiğit Botanic Garden and Flora Researh Society Publishing, 1-1290.

Hamzaoğlu E (2012) Dianthus. In: Güner A, Aslan S, Ekim T, Vural M, Babaç MT (Eds) Türkiye Bitkileri Listesi (Damarlı Bitkiler), Nezahat Gökyiğit Botanik Bahçesi ve Flora Araştırmaları Derneği Yayını, İstanbul, 333-337.

Hamzaoğlu E, Koç M, Aksoy A (2014) A new pricking Carnation (Caryophyllaceae) grows on tuff from Turkey: Dianthus aculeatus sp. nov.. Biodicon 7(2): 159-162.

Hamzaoğlu E, Koç M (2015) Dianthus burdurensis (Caryophyllaceae), a new species from South-western Turkey. Phytotaxa 233(2): 196-200. doi: 10.11646/phytotaxa.233.2.8

Hamzaoğlu E, Koç M, Aksoy A (2015a) Dianthus aticii, a new species from Turkey (Caryophyllaceae). PhytoKeys 48: 21-28. doi: 10.3897/phytokeys.48.4446

Hamzaoğlu E, Koç M, Büyük İ, Aksoy A, Aydın SS (2015b) A new serpentine-adapted carnation (Caryophyllaceae) from Turkey: Dianthus serpentinus sp. nov. Nordic Journal of Botany 33(1): 57-63. doi: 10.1111/njb.00582

Hamzaoğlu E, Koç M, Büyük İ, Aksoy A, Soydam Aydın S (2015c) Presence of Dianthus roseoluteus Velen. (Caryophyllaceae) in Turkey and a new species: Dianthus macroflorus Hamzaoğlu, Systematic Botany 40(1): 208-213. doi: 10.1600/036364415X686512

IUCN Standards and Petitions Subcommittee (2014) Guidelines for Using the IUCN Red List Categories and Criteria. Version 11. ttp://www.iucnredlist.org/documents/RedListGuidelines.pdf [accessed 20 April 2016]

İlçim A, Behçet L, Mükemre M (2013) Dianthus vanensis (Caryophyllaceae), a new species from Turkey. Turkish Journal of Botany 37: 219-224.

Levan A, Fredga K, Sandberg AA (1964) Nomenclature for centromeric position on chromosomes. Hereditas 52: 201-220. doi: 10.1111/j.1601-5223.1964.tb01953.x

Levin DA (2002) The role of chromosomal change in plant evolution. Oxford University Press on Demand, New York, 240 pp.

Menemen Y, Hamzaoğlu E (2000) A new species of Dianthus (Caryophyllaceae) from Salt Lake, Central Anatolia, Turkey. Annales Botanici Fennici 37: 285-287. 
Özhatay N, Kültür Ş (2006) Check-list of additional taxa to the supplement Flora of Turkey III. Turkish Journal of Botany 30: 281-316.

Paszko B (2006) A critical review and a new proposal of karyotype asymmetry indices. Plant

Systematics and Evolution 258: 39-48. doi: 10.1007/s00606-005-0389-2

Peruzzi L, Altınordu F (2014) A proposal for a multivariate quantitative approach to infer karyological relationships among taxa. Comparative Cytogenetics 8: 337-349. doi: 10.3897/ CompCytogen.v8i4.8564

Peruzzi L, Eroğlu HE (2013) Karyotype asymmetry: again, how to measure and what to measure? Comparative Cytogenetics 7: 1-9. doi: 10.3897/compcytogen.v7i1.4431

Peruzzi L, Leitch IJ, Caparelli KF (2009) Chromosome diversity and evolution in Liliaceae. Annals of Botany 103: 459-475. doi: 10.1093/aob/mcn230

Post GE (1932) Flora of Syria, Palestina and Sinai, Vol. 1. Beirut.

Rechinger KH (1988) Dianthus L. In: Rechinger KH (Ed.) Flora Iranica, Caryophyllaceae II, Vol. Akademische Druck-u Verlagsanstalt, Graz, 128-188.

Reeve H (1967) Dianthus L. In: Davis PH (Ed.) Flora of Turkey and the East Aegean Islands, Vol. 2. Edinburgh University Press, Edinburgh, 99-131.

Shishkin BK (1985) Dianthus L. In: Shishkin BK (Ed.) Flora of the U.S.S.R. V. 6, Bishen Singh Mahendra PalSingh \& Koeltz Scientific Books, Dehra Dun, 611-654.

Stebbins GL (1971) Chromosomal evaluation in higher plants. Edward Arnold, 1-216.

Strid A (1986) Dianthus L. In: Strid A (Ed.) Mountain Flora of Greece, Vol. 1. Cambridge University Press. Cambridge, 176-200.

Tutin TG (1964) Dianthus L. In: Tutin TG, Heywood VH, Burges NA, Valentine DH, Walters SM, Webb DA (Eds) Flora Europaea Vol. 1, Cambridge University Press, Cambridge, 188-204.

Velenovsky J (1891) Flora Bulgarica. Prostat apud Fr. Rivnac., Pragae.

Vural C (2008) A new species of Dianthus (Caryophyllaceae) from mount Erciyes, Central Anatolia, Turkey. Botanical Journal of the Linnean Society 158: 55-61. doi: 10.1111/j.10958339.2008.00843.x

Yılmaz O, Kaynak G, Daşkın R, Meriçlioğlu A (2011) Dianthus goekayi (Caryophyllaceae), a new species from Turkey. Annales Botanici Fennici 48: 74-78. doi: 10.5735/085.048.0111 